\title{
A note on variability of water extract viscosity of rye grain from north-east regions of Poland ${ }^{*}$
}

\author{
S. Smulikowska ${ }^{1}$ and V.C. Nguyen \\ The Kielanowski Institute of Animal Physiology and Nutrition, \\ Polish Academy of Sciences \\ 05-110 Jabtonna, Poland
}

(Received 26 September 2001; accepted 6 November 2001)

\begin{abstract}
The objective of the study was to compare a viscosity of water extracts of a range of commercial rye grain grown in Poland and to check if it correlates with weight of grain and protein and fibre content. In 22 samples of rye from north-eastern regions of Poland the grain weight was measured and content of crude protein determined. Samples of rye were incubated with sodium acetate buffer (WEV), or in conditions imitating in vitro digestion process - IVA (HCl-bicarbonate) and IVB (pep$\sin -\mathrm{HCl}$, pancreatin-bicarbonatc) and viscosity of subsequent water extracts was measured. The range of obtained values was from 2.4 to $15.8 \mathrm{cP}$ for WEV, from 13.6 to $240 \mathrm{cP}$ for IVA and from 17.8 to $242 \mathrm{cP}$ for IVB. Amongst viscosity values obtained by three methods was close correlation. They were not correlated with grain weight, but all were negatively correlated with crude protein content $(\mathrm{r}=-0.54,-0.58$ and -0.62 for WEV, IVA and JVB, respectively; $\mathrm{P}<0.01)$. The last 2 viscosity values were also correlated with insoluble fibre content $(\mathrm{r}=0.80 ; \mathrm{P}<0.05)$ in rye grain.
\end{abstract}

KEY WORDS: rye, viscosity, crude protein, dietary fibre, grain weight

\section{INTRODUCTION}

Winter rye performs well under soil and weather conditions of north-eastern Poland, where other crops may perform poorly. Rye grain contains pentosans, found in the endosperm cell walls, which solubilize during digestion process forming

* Supported in part by the State Committee for Scientific Research, Grant No. 5 P06E 03115

1 Corresponding author 
solutions of high viscosity. High viscosity of digesta reduces the rate of digestion and assimilation of nutrients, amongst others fat and cholesterol (Smulikowska and Mieczkowska, 1996). This effect may be considered as favourable in adult humans (Rakowska, 1996), however strongly impedes the acceptance of rye grain as a feedstuff for chickens and young pigs. Viscosity of water extracts of rye is influenced by genotype and environment (Gan et al., 1997) and correlates negatively with nutritive value of grain for young chickens (Campbell et al., 1991; McLeod et al., 1996; Boros and Bedford, 1999) and pigs (Thacker et al., 1999). McLeod et al. (1996) found, that in chickens lowering the digesta viscosity by pentosanase supplementation of ryc-based diets was more effective in improving performance than feeding cultivar having an equivalent viscosity. However McLeod et al. (1996) as well as Boros and Bedford (1999) suggested a combination of the two approaches - breeding rye for low viscosity and using enzymes - as most efficient.

The purpose of the study was to compare viscosity of water extracts of a range of commercial rye grain grown in Poland and to check if it correlates with weight of grain and protein and fibre content.

\section{MATERIAL AND METHODS}

Twenty two samples of rye grain from 1996 harvest year were collected from farmers at north-eastern regions of Poland. Sixteen of them represented the most popular in Poland cultivar Dańkowskic Złote, two Dańkowskic Nowe, two Motto and one Warko cultivar. Cultivar of one sample was not identified by a producer. Grain weight was estimated as a weight of 1000 seeds.

One hundred gram of grain was ground using a cyclone mill fitted with $0.5 \mathrm{~mm}$ screen and placed in plastic jars, which were kept open for $48 \mathrm{~h}$ to equilibrate the moisture content. Samples were analysed for dry matter and crude protein ( $\mathrm{N}$ x 6.25) content according to AOAC (1990) and used for viscosity measurements.

Water extract viscosity (WEV) was determined according to modified method of McLeod et al. (1996). One gram of ground sample was mixed with $5 \mathrm{ml}$ of sodium acetate buffer ( $\mathrm{pH}$ 5.0) for $1 \mathrm{~min}$. Tubes were sealed with a stopper, incubated for $30 \mathrm{~min}$ at $40^{\circ} \mathrm{C}$ in a shaking water bath and immediately centrifuged $\left(10 \mathrm{~min}, 12000 \mathrm{xg}\right.$ ) in a Beckman centrifuge (model J2-21) kept in temp. $4^{\circ} \mathrm{C}$. The supernatant was decanted carefully and stored on ice until viscosity was determined. Viscosity of supernatant was determined using a Brookfield Digital cone/ plate viscometer (model LVDV II+, Brookficld Enginecring Laboratories, Stoughton, MA, USA). The viscometer was maintained at $40^{\circ} \mathrm{C}$ by connecting the sample cup to a water bath, shear rates were from 90 to $225 \mathrm{~s}^{-1}$. Viscosity was expressed in centipoise ( $\mathrm{cP}=1 \mathrm{mPas} \cdot \mathrm{s})$. Six samples were tested in each incubation 
to avoid a possible decline in WEV with time caused by endogenous cnzymes. Triplicate analyses for each sample were determined in separate runs.

In vitro viscosity (IV) was determined according to modified method of Bedford and Classen (1993) without (sample A) or with (sample B) addition of pepsin and pancreatin. One gram of ground grain was placed in duplicate tubes. Then $3 \mathrm{ml} 0.1 \mathrm{~N} \mathrm{HCl}$ solution was added to the sample A (IVA) and $3 \mathrm{ml} 0.1 \mathrm{~N} \mathrm{HCl}$ solution containing 2,000 U pepsin/ml (Merck catalogue no.1.07190) was added to the sample B (IVB). The content was mixed for $1 \mathrm{~min}$, tubes were sealed with a stopper and incubated for $45 \mathrm{~min}$ in a shaking water bath at $40^{\circ} \mathrm{C}$, thereafter $1 \mathrm{ml}$ of $1 \mathrm{M} \mathrm{NaHCO}_{3}$ solution to sample $\mathrm{A}$ and $1 \mathrm{ml}$ of $1 \mathrm{M} \mathrm{NaHCO}_{3}$ solution containing $4 \mathrm{mg}$ of pancreatin to sample B was added. The content was mixed, tubes were sealed and incubated further for $2 \mathrm{~h}$ in a shaking water bath at $40^{\circ} \mathrm{C}$. Tubes were removed from the bath, cooled in ice and immediately centrifuged as was described above, viscosity of supernatant was measured at shear rates from 4.5 to $90 \mathrm{~s}^{-1}$. Each pair of samples was analysed in duplicate in separate runs.

Eight samples covering the whole range of measured WEV were analysed for insoluble (IDF) and soluble (SDF) dietary fibre by the gravimetric method of Asp et al. (1983).

Data were analysed statistically with the use STATISTICA PL program. Significance of differences between three methods of viscosity measurement was tested by Kruskal-Wallis test (Stanisz, 2001).

\section{RESULTS AND DISCUSSION}

The obtained results were shown in Table 1 . A relatively small number of newer cultivars was represented among collected samples, old cultivar Dańkowskie Złote dominated, so comparison between cultivars is not fully justified. It seems however, that differences between rye of the same cultivar grown in different locations were bigger than differences between cultivars (Table 1). Grain weight ranged from 22 to 33.8 g per 1000 seeds (Table 1) and was not significantly correlated with crude protein content in grain or with any viscosity measurements (Table 2). In set of rye samples evaluated by McLeod et al. (1996) grain weight was negatively correlated with WEV of the rye samples, however the range of grain weights presented in that paper was broader (from 24.5 to $44.5 \mathrm{~g}$ per 1000 seeds).

Water extract viscosity ranged from 2.36 to $15.83 \mathrm{cP}$ (Table 1), the range was narrower than reported by McLeod et al. (1996) who found in Canadian rye WEV from 0.8 to $26.9 \mathrm{cP}$. Viscosity values measured after incubation of samples with or without proteolytic enzymes were much higher $(\mathrm{P}<0.0001)$ and more diversified (Table 1). IVA ranged from 13.6 to $240 \mathrm{cP}$, IVB from 17.8 to $242 \mathrm{cP}$. However WEV was significantly correlated both with IVA and IVB (Table 2). The great 
TABLE 1

The grain weight, g/1000 grains, crude protein content, g/kg DM, viscosity of water extract (WEV) and in vitro without (IVA) and with (IVB) addition of proteolytic enzymes, dietary fibre content: soluble (SDF), insoluble (IDF) and total (TDF) in $\mathrm{g} / \mathrm{kg} \mathrm{DM}$, in rye grain

\begin{tabular}{|c|c|c|c|c|c|c|c|c|c|}
\hline \multirow{2}{*}{$\begin{array}{c}\text { Sample } \\
\text { no }\end{array}$} & \multirow{2}{*}{ Cultivar } & \multirow{2}{*}{$\begin{array}{c}\text { Grain } \\
\text { weight }\end{array}$} & \multirow{2}{*}{$\begin{array}{l}\text { Crude } \\
\text { protein }\end{array}$} & \multicolumn{3}{|c|}{ Viscosity, cP } & \multicolumn{3}{|c|}{ Dictary fibre } \\
\hline & & & & WEV & IVA & IVB & SDF & IDF & TDF \\
\hline 1 & Motto ${ }^{1}$ & 26.8 & 94.2 & 7.93 & 108.8 & 127.3 & & & \\
\hline 2 & Motto & 28.1 & 89.5 & 10.12 & 115.3 & 124.6 & & & \\
\hline 3 & Dańkowskic Nowe ${ }^{3}$ & 27.9 & 82.6 & 11.24 & 147.9 & 193.5 & & & \\
\hline 4 & Dańkowskie Nowe ${ }^{5}$ & 22.8 & 77.9 & 15.83 & 240.2 & 242.4 & & & \\
\hline 5 & Warko ${ }^{9}$ & 29.2 & 77.8 & 12.10 & 99.7 & 101.6 & & & \\
\hline 6 & Unknown ${ }^{7}$ & 29.2 & 93.0 & 8.14 & 102.0 & 122.6 & & & \\
\hline 7 & Dańkowskic Złote & 31.1 & 100.4 & 6.72 & 45.6 & 52.1 & 67.1 & 129.0 & 196.1 \\
\hline 8 & Dańkowskie Zlote & 24.4 & 106.6 & 10.69 & 133.1 & 135.5 & & & \\
\hline 9 & Dańkowskie Złote ${ }^{2}$ & 30.7 & 87.7 & 6.52 & 42.9 & 46.0 & 63.4 & 133.5 & 196.9 \\
\hline 10 & Dańkowskie Zlote ${ }^{3}$ & 33.8 & 75.7 & 12.07 & 86.5 & 86.6 & 56.0 & 131.3 & 187.3 \\
\hline 11 & Dańkowskie Złote ${ }^{3}$ & 30.4 & 76.8 & 9.36 & 158.8 & 195.7 & & & \\
\hline 12 & Dańkowskie Złote & 29.2 & 80.7 & 13.50 & 202.5 & 243.5 & 52.6 & 148.8 & 201.4 \\
\hline 13 & Dańkowskie Złote ${ }^{4}$ & 30.8 & 76.4 & 6.50 & 115.1 & 153.0 & & & \\
\hline 14 & Dańkowskie Zlotes & 26.1 & 83.1 & 8.45 & 99.6 & 186.6 & & & \\
\hline 15 & Dańkowskie Zlote ${ }^{5}$ & 25.4 & 91.5 & 9.85 & 67.7 & 70.5 & 61.7 & 139.4 & 201.1 \\
\hline 16 & Dańkowskie Zlote $\mathrm{e}^{\text {tr }}$ & 25.7 & 102.3 & 2.36 & 13.6 & 17.8 & & & \\
\hline 17 & Dańkowskie Złote ${ }^{6}$ & 25.6 & 96.5 & 10.70 & 85.6 & 97.8 & & & \\
\hline 18 & Dańkowskic Ztote ${ }^{8}$ & 27.8 & 99.2 & 3.87 & 27.1 & 26.6 & 38.9 & 135.6 & 174.5 \\
\hline 19 & Dańkowskie Złote ${ }^{8}$ & 29.6 & 97.8 & 6.12 & 49.0 & 44.1 & & & \\
\hline 20 & Dańkowskie Złote ${ }^{x}$ & 30.7 & 89.8 & 5.90 & 78.6 & 78.9 & 65.5 & 134.8 & 200.3 \\
\hline 21 & Dańkowskie Złote? & 22.0 & 91.2 & 8.94 & 90.1 & 93.2 & & & \\
\hline 22 & Dańkowskie Złote & 22.9 & 103.2 & 7.96 & 61.9 & 66.9 & & & \\
\hline Mean & & 27.7 & 89.7 & 8.86 & 98.1 & 110.8 & 57.9 & 136.1 & 193.9 \\
\hline Median & & & & $8.69^{A}$ & $94.8^{\mathrm{Bb}}$ & $99.7^{13 c}$ & & & \\
\hline SD & & 3.1 & 9.7 & 3.14 & 53.3 & 60.8 & 9.8 & 6.5 & 9.8 \\
\hline
\end{tabular}

1-10 superscripts indicates on the Agriculture Extension Centre from where the rye sample was supplied; each sample originated from different farm in vicinity of a Centre: 1 - Bratoszewice, 2 - Siedlce, 3 - Stare Pole, 4 - Olsztyn, 5 - Olecko, 6 - Bonin, 7 - Ostrolęka, 8 - Modliszewice, 9 - Poświętne, 10 - Lubniewice

${ }^{a b A B}$ - the median values of viscosity measurement were different at ${ }^{a b}-P<0.05 ;{ }^{A B}-P<0.001$

numerical differences between the average value of viscosity measured as WEV and IVA and IVB may be connected with the higher proportion of sample to the liquid and longer time of incubation in the in vitro methods. Annison (1995) showed, that in dilute solutions viscosity increases linearly with a concentration of the viscous molecules, but beyond critical concentration, when molecules begin to interact and become entangled viscosity increases at a greater rate. 
TABLE 2

The calculated correlation between rye extract viscosity and some grain characteristics

\begin{tabular}{lcccccc}
\hline & WEV & IVA & IVB & $\begin{array}{c}\text { Grain } \\
\text { weight }\end{array}$ & $\begin{array}{c}\text { Crude } \\
\text { protein }\end{array}$ & SDF \\
\hline IVA & $0.816^{* * *}$ & & & & & \\
IVB & $0.698^{* * *}$ & $0.934^{* * *}$ & & & & \\
Grain weight & -0.152 & -0.152 & -0.134 & & & \\
Crude protein & $-0.531^{* *}$ & $-0.579^{* *}$ & $-0.619^{* *}$ & -0.398 & & \\
SDF & 0.061 & -0.050 & 0.005 & 0.263 & -0.021 & \\
IDF & 0.539 & $0.799^{*}$ & $0.777^{*}$ & -0.509 & -0.332 & -0.327 \\
\hline
\end{tabular}

WEV - water extract viscosity, IVA, IVB - viscosity of extract after in vitro digestion, SDF - soluble-, IDF - insoluble dictary fibre; * $\mathrm{P}<0.05 ; * * \mathrm{P}<0.01 ; * * * \mathrm{P}<0.001$

It seems that in vitro method proposed by Bedford and Classen (1993) as a rapid screening method for enzyme sources selected for use in poultry rations may be also useful for predicting viscosity of different samples of rye and its usefulness in poultry and swine diets. The more diversified values obtained by this method (Table 1) may allow for easier screcning for grain quality.

The samples having the most diversified WEV were chosen for dietary fibre determination. The content of soluble dietary fibre in grain ranged from 39 to $67 \mathrm{~g} /$ $\mathrm{kg} \mathrm{DM}$, insoluble dictary fibre ranged from 129 to $150 \mathrm{~g} / \mathrm{kg} \mathrm{DM}$; in total from 175 to $200 \mathrm{~g} / \mathrm{kg}$ DM of rye grain was determined as dietary fibre (Table 1). The respective values reported by Boros and Bedford (1999) for 4 rye hybrids selected in Institute of Plant Breeding and Acclimatization at Radzików (Poland) were lower, SDF ranged from 39 to 47 , IDF from 106 to 119 , TDF from 147 to $158 \mathrm{~g} / \mathrm{kg} \mathrm{DM}$. Contrary to Boros and Bedford (1999) in present investigation SDF content was not significantly correlated with WEV (Table 2). It was found however that IDF content is positively correlated with IVA and IVB (Table 2).

The significant positive correlation of IVA and IVB with insoluble dietary fibre content in grain indicates, that during relatively long time of incubation in conditions similar to those in gastrointestinal tract of monogastric animals, some dietary fibre components of rye determined chemically as insoluble are solubilized, increasing the viscosity of solution. The proteolytic enzymes added into incubation medium in about $70 \%$ of samples had no significant effect on viscosity of extract, however in about $30 \%$ of evaluated samples the difference between IVB and IVA was relatively big, the difference between mean IVA and IVB values was statistically significant at $\mathrm{P}<0.05$. IVA was strongly correlated with IVB (Table 2 ).

Crude protein content averaged about 90 and ranged from 76 to $107 \mathrm{~g} / \mathrm{kg} \mathrm{DM}$. Crude protein content in grain was not significantly correlated with soluble or insoluble dietary fibre content, but it was significantly negatively correlated with 
all viscosity measurements (Table 2 ). It means that pentosans in low protein rye are more viscous, so such rye not only supplies less amino acids but may additionally disturb digestion and absorption of other dietary components in young animals due to more viscous property of water-soluble polysaccharides. The strongest negative correlation of crude protein content with IVB may indicate that in grain of the lower protein content proportionally more protein are bound with dietary fibre components making the complexes insoluble. Enzymatic digestion of protein present in this complexes may cause release and further solubilization of the bigger amount of viscous components of dietary fibre. Rakowska (1996) suggested that, when breeding for improvement of feed quality of rye, selection of inbred lines should be performed for lower water extract viscosity and for higher protein content. It seems that this suggestions are fully justified.

In practical conditions the crude protein content in rye grain may be good indicator of nutritional value of rye for young animals. Negative correlation between crude protein content in rye grain and viscosity of extracts obtained after digestion in vitro indicates, that low protein rye, due to high viscosity, may to the greater extent disturb digestion and absorption of dietary components in young animals than high protein rye.

\section{ACKNOWLEDGEMENTS}

The Agriculture Extension Centres at: Bratoszewice, Siedlce, Stare Pole, Olsztyn, Olecko, Bonin, Ostrołęka, Modliszewice, Poświętne and Lubniewice are greatly acknowledged for supplying the rye samples.

\section{REFERENCES}

Annison G., 1995. Feed enzymes - the science, future developments and practical aspects in feed formulation. Proceedings of $10^{\text {th }}$ European Symposium on Poultry Nutrition, Antalya (Turkey), pp. 193-201

AOAC, 1990. Association of Official Analytical Chemists. Official Methods of Analysis. 15 $5^{\text {th }}$ Edition. Arlington, $\mathrm{VA}$

Asp N-G., Johansson C-G., Hallmer H., Sijestrom M., 1983. Rapid enzymatic assay of insoluble and soluble dietary fibre. J. Agr. Food Chem. 31, 476-482

Bedford M.R., Classen H.L., 1993. An in vitro assay for prediction of broiler intestinal viscosity and growth when fed rye-based diets in the presence of exogenous cnzymes. Poultry Sci. 72, $137-143$

Boros D., Bedford M.R., 1999. Influence of water extract viscosity and exogenous enzymes on nutritive value of rye hybrids in broiler diets. J. Anim. Feed Sci. 8, 579-588

Campbell G.L., Teitge D.A., Classen H.L., 1991. Genotypic and environmental differences in rye fed to broiler chicks with dietary pentosanase supplementation. Can. J. Anim. Sci. 71, 1241-1247 
Gan J.G., McLeod J.G., Scoles G.J., Campbell G.L., 1997. Extract viscosity of winter ryc: variation with temperature and precipitation. Can. J. Plant Sci. 77, 555-560

McLeod J.G., Gan Y., Scoles G.J., Campbell G.L., 1996. Extract viscosity and feeding quality of rye. Vortr. Pflanzenzüchl. 35, 97-108

Rakowska M., 1996. The nutritive quality of rye. Vortr. Pflanzenzücht. 35, 85-95

Smulikowska S., Micczkowska A., 1996. Effect of rye level, fat source and enzyme supplementation on fat utilization, diet metabolizable energy, intestinal viscosity and performance of broiler chickens. J. Anim. Feed Sci. 5, 379-393

Stanisz A., 2001. Popular Course in Statistes Based on STATISTICA PL (in Polish). $2^{\text {nd }}$ Edition. StatSoft Polska, Kraków

Thacker P.A., Campbell G.L., Scoles G.J., 1999. Performance of young growing pigs (17-34 kg) fed rye-based diets selected for reduced viscosity. J, Anim. Feed Sci. 8, 549-556

\section{STRESZCZENIE}

\section{Zmienność lepkości wodnego ekstraktu ziarna żyta pochodzącego z północno-wschodnich re- jonów Polski}

Celem pracy było porównanie lepkości ekstraktów wodnych z żyta różnych odmian uprawianych w Polsce i sprawdzenie czy jest ona skorelowana z niektórymi cechami ziama. W 22 próbkach żyta pochodzącego z pólnocno-wschodnich rejonów Polski zmierzono masę zianiaków i oznaczono zawartość białka ogólnego. Próbki inkubowano z buforem octanowym (WEV) lub in vitro w warunkach imitujących początkowe stadia trawienia u zwierząt monogastrycznych: IVA (kolejno $z$ roztworami $\mathrm{HCl}$ i $\mathrm{NaHCO}_{3}$ ) lub IVB (kolejno z roztworami $\mathrm{HCl}$-pepsyna i $\mathrm{NaHCO}_{3}$-pankreatyna), po czym mierzono lepkość ekstraktu wodnego. Zakres otrzymanych wartości dla WEV wynosił od 2,4 do $15,8 \mathrm{cP}$, dla IVA od 13,6 do $240 \mathrm{CP}$, dla IVB od 17,8 do $242 \mathrm{cP}$. Wartości lepkości ekstraktów otrzymane przy użyciu wszystkich metod byly dodatnio skorelowane miçdzy soba, a ujemnie z zawartością białka ogólnego w zianie żyta $(\mathrm{r}=-0,54,-0,58 \mathrm{i}-0,62$, odpowiednio dla WEV, IVA i IVB; $\mathrm{P}<0,0 \mathrm{I})$. Ostatnic dwic wartości były dodatnio skorclowane z zawartością nierozpuszczalnego włókna pokarmowego $(\mathrm{r}=0,80 ; \mathrm{P}<0,05)$ w ziarnie żyta. 